\title{
Spontaneous subdural haematoma in a paediatric patient on anticoagulant therapy
}

\author{
Islam F Fayed, ${ }^{1}$ Yonmee Chang, ${ }^{2}$ Robert F Keating, ${ }^{3}$ Srijaya K Reddy ${ }^{2}$
}

'Department of Neurosurgery, MedStar Georgetown University Hospital, Washington, District of Columbia, USA

${ }^{2}$ Division of Anesthesiology, Pain and Perioperative Medicine,

Children's National Health

System, Washington, District of Columbia, USA

${ }^{3}$ Division of Neurosurgery, Children's National Health

System, Washington, District of Columbia, USA

Correspondence to Dr Srijaya K Reddy, sreddy@cnmc.org

Accepted 24 October 2017

CrossMark

To cite: Fayed IF, Chang Y, Keating RF, et al. BMJ Case Rep Published Online First: [please include Day Month Year]. doi:10.1136/bcr-2017223041

\section{DESCRIPTION}

A 5 -year old girl with congenital mitral and subaortic stenosis on anticoagulant therapy since her mechanical mitral valve replacement, and a remote history of idiopathic intrahepatic cholestasis requiring liver transplantation presented with jaundice and pruritus. She was found to have elevated transaminases, and an echocardiogram revealed significantly increased right ventricular pressures concerning for pulmonary hypertension. Subsequently, the patient needed to be intubated for respiratory insufficiency and poor cardiac output. After several days in the intensive care unit (ICU), she was noted to be bradycardic and have a dilated right pupil. A stat CT of the head demonstrated a large mixed density right-sided subdural haematoma with mass effect, midline shift and early uncal and transtentorial herniation, as well as a small subdural haematoma on the left (figure 1). The mixed density of the haematoma on CT scan was likely a result of multiple haemorrhages over the previous several days and/or hyperacute blood product accumulation in the setting of a coagulopathy.

The patient was taken to the operating room for emergent decompressive craniectomy and evacuation of subdural haematoma. Prior to surgery, her coagulopathy was reversed with protamine, decreasing her PTT from 150 to $37 \mathrm{~s}$. The patient was also given mannitol and hyperventilated as temporising measures while the operating room

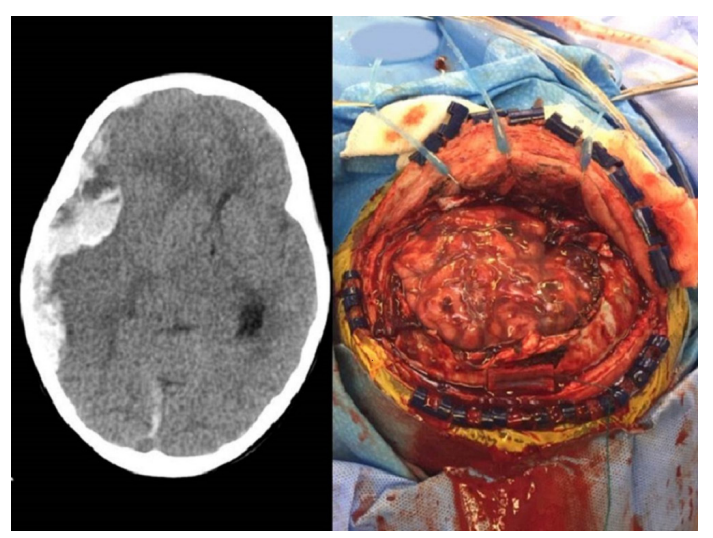

Figure $1 \mathrm{CT}$ of the head showing right-sided subdural haematoma with mass effect, midline shift and a small subdural haematoma on the left and swollen brain parenchyma with mottled appearance after evacuation of subdural haematoma and decompressive craniectomy. was being prepared. A large right frontotempoparietal craniectomy was performed in standard fashion. Removal of the bone flap revealed impressive swelling and tense dura with a blue tint. The dura was then opened progressively to avoid herniation of brain tissue or hypotension. Extensive mixed density clot was evacuated to reveal markedly swollen brain parenchyma with a mottled appearance, likely due to a combination of cerebral contusions from the mass effect of the haematoma as well as the patient's underlying venous hypertension (figure 1). After a satisfactory and uneventful decompression, an ICP monitor was placed, the bone flap was left off and the skin was closed in routine fashion. The patient was kept intubated and transported back to the ICU for further management.

\section{Learning points}

- Monitoring the neurological examination of patients on anticoagulation, particularly those who are intubated, is critical in early detection of intracranial haemorrhage. ${ }^{1}$

- Venous hypertension that involves the cerebral vasculature can predispose patients to develop intracranial haemorrhages, and, in this case, cause a mottled, haemorrhagic appearance of the brain parenchyma. ${ }^{2}$

Contributors IFF was responsible for the initial written content and obtaining images. YC was responsible for reviewing and editing the manuscript and providing images for this case. RFK was responsible for reviewing and editing the manuscript. SKR was responsible for reviewing and editing as well as creating the final image for submission. All authors have approved this final manuscript.

Competing interests None declared.

Patient consent Guardian consent obtained.

Provenance and peer review Not commissioned; externally peer reviewed.

(c) BMJ Publishing Group Ltd (unless otherwise stated in the text of the article) 2017. All rights reserved. No commercial use is permitted unless otherwise expressly granted.

\section{REFERENCES}

1 Mattle $H$, Kohler S, Huber $\mathrm{P}$, et al. Anticoagulation-related intracranial extracerebral haemorrhage. J Neurol Neurosurg Psychiatry 1989;52:829-37.

2 Prada LF, Gavilanes F, Souza R. Incidence of spontaneous subdural hematoma in incident cases of pulmonary arterial hypertension: a registry of cases occurring over a five-year period. J Bras Pneumol 2015;41:101-2. 
Copyright 2017 BMJ Publishing Group. All rights reserved. For permission to reuse any of this content visit http://group.bmj.com/group/rights-licensing/permissions.

BMJ Case Report Fellows may re-use this article for personal use and teaching without any further permission.

Become a Fellow of BMJ Case Reports today and you can:

- Submit as many cases as you like

- Enjoy fast sympathetic peer review and rapid publication of accepted articles

Access all the published articles

- Re-use any of the published material for personal use and teaching without further permission

For information on Institutional Fellowships contact consortiasales@bmjgroup.com

Visit casereports.bmj.com for more articles like this and to become a Fellow 